\title{
ANALYSIS OF CHARACTER VALUES IN THE TRADITIONAL GAMES COLLECTION OF SEREN TAUN CUSTOM RITUALS: AN ETNOGRAPHIC STUDY
}

\author{
Gilang Kripsiyadi Praramdana', Febby Fajar Nugraha ${ }^{2}$ \\ ${ }^{1}$ Universitas Kuningan \\ ${ }^{2}$ Universitas Kuningan \\ 1'gilang.kripsiyadi@uniku.ac.id, ${ }^{2}$ febbyfajar@uniku.ac.id
}

\begin{abstract}
Character education has a major aim to develop quality and excel the human resources. It is based on the Republic of Indonesia's National Education Objectives. The values of this nation's character education are embedded in the ancestral heritage, one of them is a traditional game. The descriptiveanalytic method with an ethnographic approach that we used in this study was to analyze and describe the phenomena. Therefore, we chose the Spradley ethnographic method (cognitive anthropology) as a method with phased progressive research (The Developmental Research Sequence). Based on 15 traditional games in the Ritual AdatSerenTaun in Cigugur, we have classified potential major character values which include: (1) five (33\%) types of games have independent major character values; (2) seven (46\%) types of games have gotongroyong major character values; and (3) four (27\%) types of games have integrity major character value. While both religious and nationalist major character values have not been found based on our analysis of 15 types of games in this study.
\end{abstract}

Keywords: charactervalue, traditional games, serentaun

\begin{abstract}
Abstrak
Pendidikan karakter memiliki tujuan utama untuk mengembangkan sumber daya manusia yang berkualitas dan unggul. Hal ini dilatarbelakangi dari Tujuan Pendidikan Nasional Republik Indonesia. Nilai-nilai pendidikan karakter bangsa ini tertanam dalam warisan leluhur, salah satunya permainan tradisional. Metode deskriptif analitik dengan pendekatan etnografi yang kami gunakan dalam penelitian ini untuk menganalisis dan mendeskriptifkan fenomena. Oleh karena itu, metode etnografi Spradley (antropologi kognitif) kami pilih sebagai metode dengan alur penelitian maju bertahap (The Developmental Research Sequence). Berdasarkan 15 permainan tradisional di Ritual Adat Seren Taun di Cigugur, kami telah mengklasifikasikan potensi nilai karakter utama yang meliputi: (1) lima (33\%) jenis permainan memiliki nilai karakter utama mandiri; (2) tujuh (46\%) jenis permainan memiliki nilai karakter utama gotong royong; dan (3) empat (27\%) jenis permainan memiliki nilai karakter utama integritas. Sedangkan nilai karakter utama reigius dan nasionalis belum ditemukan berdasarkan analisis kami terhadap 15 jenis permainan dalam penelitian ini.
\end{abstract}

Kata Kunci: nilai karakter, permainan tradisional, seren taun.

\section{INTRODUCTION}

The influence of technological developments in the industrial era 4.0 is very obviousespecially in devices or smartphones consumption. Moreover, there are claims saying that young generation more often play gadgets in their spare time. It is feared that this phenomenon will only produce generation with high individualism attitude but low socialization ability, and consequently, the Indonesian people's typical traditional games (local wisdom of noble heritage) are increasingly forgotten. Furthermore, in comparison to other physical activities, the phenomenon of using devices/smartphones entrenched in the past 5 
(five) years is also very tangible, creating more intense cultural shift. Through this phenomenon, the influence of globalization is increasingly eroding the awareness of Indonesians' young generation on the heritage of noble cultural traditions, so that we need more solutions to re-introduce Indonesian cultural heritage (Wibowo, 2008).

The above phenomena reflect that, in the current condition, there has been decreased awareness of the existence of Indonesia's cultural heritage, especially traditional games and activities. In fact, these traditional games activities have positive values such as the superiority of physical activity, like training fine \& gross motor skills, besides, that in traditional games, there is absolute value of cooperation (one of the character values), dexterity and integrity values (character), and the potential value of other characters. One of ethnic groups still preserving cultural values is the Sundanese in the Cigugur Region of Kuningan Regency with its culture, SerenTaun Traditional Ritual. In essence, SerenTaun Traditional Ritual deals with gratitude for the abundant harvest expressed in a traditional ritual (Adisaputri \& Widiastuti, 2015; Holilah, 2015; Kurnia, 2014; Subiantoro, 2017). This traditional ritual in Cigugur Kuningan District is closely related to the relationship between humans and their environment. The environment must always be maintained and preserved for the sake of inheritance to future generations. Cigugur community preserves the environment by instilling local cultural values which are then bequeathed from generation to generation. Then, Aditya (2013) states that the formation of students' character can be done by introducing them to local cultures. That is because the traditions carried out by local people contain wisdom values or morality as in children traditional game in the customary procession of SerenTaun in which there is the value of character establishment, for example, in Bebentengan Kaulinan (Sundanese children traditional game broadly divided into two groups), there is the value of cooperation and responsibility.

Several ethnographic studies in the past research have been carried out e.g.: a) Kamarusdiana (2019) with a research focus entitled "Ethnographic Studies in the Framework of Society and Culture", the purpose of this research is to implement ethnographic studies to discuss cultural aspects that exist in our archipelago's society. And how important is the study/ethnographic approach as an alternative form in carrying out cultural research in this society, and b) Hemafitria (2019) with the title of the study "Character Values Based on Local Wisdom Tradition of Tepung Segar in the Sambas Malay Ethnic" based on her findings that the Tepung Segar Tradition has Character Values Based on the Local Wisdom of the Sambas Malay Community, which includes the tradition of the Tepung Segar creates: (1) religious 
values, gratitude can be contextualized into a religious character, (2) the value of unity with nature can be contextualized into a character of responsibility and discipline, and (3) social values, love, and compassion, also because safety and a good life can be contextualized into characters of love, care, and cooperation. Based on this explanation and for the sake of this study, the researcher tries to focus on the application of the ethnographic approach as a "knife" in collecting data empirically, starting from the investigation of the Cigugur indigenous people and their Seren Taun culture, to particularly the character values or morality in the collection of traditional games in the traditional rituals of Seren Taun. Then the writer focuses on the values of character in Seren Taun Traditional Ritual procession where there are values that can be adapted into learning in order to instill the values of characters. In addition, this research also supports the wealth of local culture to be preserved through formal learning later.

\section{METHOD}

In general, Suyatna (2007) explains that descriptive research method is a mixture of basic data, descriptive, has one hypothesis, does not make predictions or look for implications. The method used in this study is descriptive analytic method with ethnographic approach in the form of descriptive phenomenology and evidence. The ethnographic method used in this study is Spradley ethnographic method, namely cognitive anthropology known as the phased forward research flow method (The Developmental Research Sequence) (Spradley, 2007).

The Cigugur custom in the Seren Taun ritual is strengthened by the data collection methods used were qualitative, namely in the form of interviews and participant observation. While the data source obtained in this study is one of the traditional leaders of Seren Taun in Cigugur, by means of comprehensive interviews focusing on traditional games, and the data is also supported by existing libraries, both in the form of related books and journals that have correlation with the problems. Relevant to the theory of Emerson, Fretz, \& Shaw (1995), "ethnographic field research involved study of groups and people as they go about their everyday lives". Generally, ethnographic research has the potential to produce two different activities. First, we tried to enter the social setting and deepens knowledge about the Cigugur indigenous people who routinely carried out the Seren Taun tradition every year. Therefore, we intimately participates in the daily routine of several traditional Seren Taun leaders, so that they could coincide with traditional observations (traditional games within the community).

Furthermore, the data already obtained is then analyzed in depth in order to look for character values in it. Then we record or writes the results research periodically, in a systematic 
way from things that were observed and studied. The final stage of the researcher was to make an accumulation of what has been experienced in the field by transforming ideas according to field conditions, especially the potential or interpretation of character values in traditional games..

\section{RESULTS AND DISCUSSION}

\section{Results}

Character Values

The definition of Character, according to the Language Center of the Ministry of National Education (Kemdiknas, 2010), is innate, heart, soul, personality, trait, behavior, personality, temperament and nature. Someone having character is he or she that has personality, behavior, trait, and nature. Lickona (2012)explains the definition of good character as living life with truth. The truth is related to attitudes toward self and others. Ministry of National Education (Kemdiknas, 2010) now known as the Ministry of Education and Culture (Ministry of Education and Culture) divides Character Values into 18, including: (1) Religious, (2) Honest, (3) Tolerance, (4) Discipline, (5) Hard work, ( 6) Creative, (7) Independent, (8) Democratic, (9) Curiosity, (10) Nationalism, (11) Loving motherland, (12) Appreciating achievement, (13) Friendly/communicative, (14) Loving peace, (15) Reading fondness, (16) caring environment, (17) Social care, (18) Responsibility. In the meantime, the five main values of character (Kemdikbud, 2014) are not values that stand and develop individually but values that interact with others, which develop dynamically and form personal wholeness. The five main values of the intended national character are as follows: 1) Religious; reflecting faith in God Almighty which is manifested in the behavior of implementing religious teachings and beliefs that are held, respecting religious differences, upholding a tolerant attitude towards the implementation of religious worship and other beliefs, living in harmony and peace with followers of other religions, 2) Nationalists; a way of thinking, behaving, and acting that shows loyalty, care and high respect for the language, physical environment, social, cultural, economic, and political of the nation, placing the interests of the nation and state above self and group interests, 3) Independent; an attitude and behavior that does not depend on others and uses all energy, thoughts, time to realize hopes, dreams and ideals, 4) Mutual Cooperation; reflects the act of appreciating the spirit of cooperation and working hand in hand to resolve common problems, establish communication and friendship, provide assistance/help to people in need and 5) Integrity; a value that underlies behavior based on efforts to make oneself a 
person who can always be trusted in words, actions, and work, has commitment and loyalty to human values and morals (moral integrity). From the descriptions of character values above, what are character values and how character values manifested in the values of ancient traditions, such as traditional games, maybe traditional arts we thought. Finally, we were focused on studying traditional games in the traditional rituals of Seren Taun in the indigenous Cigugur community which potential character values within as explained below.

\section{Traditional Games in Cigugur Seren Taun Custom Rituals}

\section{Seren Taun Custom Rituals}

The term Seren Taun is originally derived from Sundanese language word seren which means "handover/turn over" and taun which means "year". Seren Taun is a manifestation of the West Java farmer community in gratitude for all agricultural products carried out this year while hoping for increased agricultural harvest in the following year (Subiantoro, 2016). Gratitude is directed towards God Almighty for the gifts that have been received and trying to implement that gratitude by maintaining balance and preserving the natural environment (Aditya, 2013). The celebration is held when the harvest season arrives. As the tradition in other agrarian ethnic groups, the harvest season is always something that everyone longs for and is seen as a result of collaboration of trust and hard work (Kurnia, 2014). Seren Taun custom rituals involve various aspects of ritual to foster harmonious relations between humans and God, nature, and others (Subiantoro, 2016). The Sundanese culture of Cigugur community is inseparable from its development in the past until it remains sustainable until now. That is because it is a form of community efforts to preserve Sundanese culture as an identity of community group. SerenTaun in Kuningan is created as a tradition in the Sunda Djawa Religion or Sundanese Wiwitan by its founder, Pangeran Sadewa Madrais Alibasa Kusuma Ningrat (here in after referred to as Kyai Madrais) around the end of nineteenth century. Kyai Madrais is a descendant of Pangeran Gebang, which is a fractional region of Cirebon Sultanate which is now the Kuningan Regency. In addition, Kyai Madrais is also a Muslim teacher who teaches Islam with many philosophical elements from their own cultural roots as a Sundanese. The spiritual teachings of Kyai Madrais and how he struggled during the colonial period are inseparable. Seren Taun was born due to Dutch pressure which then fostered a high sense of nationalism. Seren Taun became a symbol of expression to live the values of nationality and humanity as non-physical resistance to Dutch colonial era (Holilah, 2015; Kurnia, 2014; Subiantoro, 2016; Suhaenah, Rohaeni, \& Listiani, 2017). The form of SerenTaun Ritual in Cigugur according to Research (Royyani, 2008) reveals the meaning of 22nd date of 
Rayagung(one of Islamic calendar months) chosen as the peak day of Seren Taun custom Ritual. Rayagung month was chosen as the symbol of the celebration of the Greatness of God. The number 22 has a symbolic meaning which when divided into two parts is a fraction and a unit. Fraction of number 20 has the meaning of character that living creatures have. These 20 characteristics are blood, flesh, feathers, nails, hair, skin, veins, brain, lung, liver, spleen, subconscious, gall, bones, marrow, fat, stomach, intestine, kidney and heart. In the meantime, number 2 means balance, because everything always consists of two elements, for example positive-negative, day-night, and male-female. In addition, the number 22 is then used as the amount of weight of the harvested rice ( 22 kilos) which will be pounded and then the rice is distributed to people who need 20 kilos and the other 2 kilos are used as the seeds to be planted. Seren Taun traditional ritual which is actually a form of gratitude for agricultural products and "moral appeal" to humans to respect nature then uses the attributes of materials from nature during the process. The handover of various agricultural products produced, especially rice, is a form of this gratitude expression (Royyani, 2008). A series of traditional rituals are intended to uphold the interaction of fertility symbols believed by Cigugur people in Kuningan, attached to the mother goddess, Nyi Pwah Aci Sang Hyang Asri, also known as Dewi Sri (Adisaputri \& Widiastuti, 2015).

Based on the results of primary interviewees by the researchers, Seren Taun procession is carried out in four ritual activities for seven days as follows:

a. The ritual begins on the 18th of Rayagung, which is an opening ritual called damarsewu which means a thousand lanterns, to light the soul.

b. The second ritual is on the 19th of Rayagung, which is a Dadung party which is an expression of the activity of farmers' love in working and praying, in managing rice fields and livestock from all kinds of disturbances (pests).

c. The third ritual is on 21 st ofRayagung, which is a spiritual hymn night as the spiritual activities of various religions, customs and beliefs.

The last ritual as the top of SerenTaunison 22nd of Rayagung. The peak of Seren Taun consists of presenting art; among others are: (a) Ngajayak, as an offering of agricultural harvested products (various fruits and seeds), (b) Babarit, as a series of spiritual songs and prayers or mantras called Rajah Pwahaci. Then, it proceeds to pounding rice, and it is ended by the party or eat together.

\section{Traditional Games}

Traditional games are actually not only inherent with Seren Taun traditional ritual procession, but also with children daily lives since the old times. Purwaningsih (2006) put it 
that traditional games are all forms of games that have existed since the old times and have been bequeathed from generation to generation. Butinequality occurs when the younger generation does not preserve it, which may be caused by the times. In fact, according to Nur (2013), returning children's traditional games today can be an alternative to creating a generation of superior character. Furthermore, traditional games have several benefits of traditional games in shaping children's characters, which are as follows (Andriani, 2012):
a. Through traditional games, children will always create nuances of joy
b. They build the game together
c. Children's skills are always honed, they are accustomed to make games from various materials around them
d. The use of game materials is always inseparable from nature
e. Such a close relationship creates appreciation of human life reality
f. Through games, children begin to get to know participatory education models

\section{Traditional Games of SerenTaun Custom Ritual in Cigugur Kuningan Regency}

From the results of the field interviews, through a comprehensive interview and documentation technique, to one of primary sources of SerenTaun traditional performers, it is found that there are 15 (fifteen) traditional games often raised or documented in every Rayagung22nd of Seren Taun ritual procession in Cigugur Kuningan Regency, among others:

(1) ambil-ambilan, (2) Ayang-ayanggung, (3) Babandringan, (4) Cingcangkeling, (5) Egrang, (6) Endeuk-endeukan, (7) Gatrik, (8) Hahayaman, (9) ) Het-Het Embe Janggotan, (10) Maen Rebutan (Panjat Pinang), (11) Oray-orayan, (12) Pacici-cici putrid, (13) Paciwit-ciwit Lutung, (14) Perengket jengkol, (15) Saptonan/Equestrian spearhead. And following is the description of pattern and shape of the game:

a. Ambil-ambilan. this is actually a (Sundanese folk song) or accompaniment kakawihan and the way children play is in the form of dialogue between someone against a person or group against a group (children who are playing in groups) while singing (cured)

$\mathrm{X}$ : Ambil-ambilan, turktukhayamsamantu

Y: Saha nu diambil kami mahteubogaincu, bogaogeanakpahatu

$\mathrm{X}$ : Pahatugedaekpurahnutu, purahngejo, purahngasakanbaligo

$Y$ : Nyerieunsukuna, kacugakkukaliage

$\mathrm{X}$ : Ayaubarnakulitmundingcampuragetigulingnyocolandage

b. Ayang-ayanggung: this song is commonly used in children's games, which have an understanding of cooperation (Rosidi, 2000) 
c. Babandringan: Type of child game for pitting yarn strength: now using glazed yarn, formerly using ramatcau (banana fiber)

d. Cingcangkeling: this song is commonly used in children's games (kakawihan) for 8-12 years old. Children sing the faster the tempo is faster, there is no complete explanation, but based on meaning is a together song,

e. Egrang: this is the children game that uses a modified pole or stick media with a footrest as high as $30-50 \mathrm{~cm}$ above ground level, with the aim of maintaining balance. and do games when free time in groups

f. Endeuk-endeukan: In the past, it was a children's game of shaking the branches they were sitting on, while singing the barahututan (kakawihan), usually having the meaning of togetherness,

g. Gatrik (tokle): this is Children's play, using two sticks of wood / bamboo or rattan, one long and one short, a short size of 10-12.5 cm, a length of 30-37.5 cm, and a diameter of 1-2 cm. and other equipment, two bricks installed at a distance of 7-10 cm, where to place the short bamboo keratin. Then how to play it. Each group/individual takes a suten, which wins a suten/suit, starts first. Putting shorter wood to be hit/pruned with long bamboo to be thrown as far as possible, and the loser tries to catch the thrown wood, if the one who catches gets 10 points, and if not must throw the bamboo/short wood in the direction of two brick, if the brick is successfully nudged he takes over the game, and so on.

h. Hahayaman: this is the Children's play, depicting a chicken being chased by a weasel in a cage-shaped cage keeper holding hands, and determining the child to be a weasel or a chicken in a lottery, and other children who not elected to form a circle to become a cage, chickens try not to be caught by the weasel and play areas in and out of the circle formed, until caught and or the weasel is exhausted and gives up unable to catch the chicken. Previously this game was played on a bright full moon in front of the yard of the house which was quite relieved and more often in the afternoon.

i. Het-het embe janggotan: This is the children Sundanesesong (kakawihan), usually sung when they gather and play in the house with salendro notation, has the meaning of togetherness.

j. Maen Rebutan (panjat pinang): this game is played in an arena of agility with the number of players per group of 4-5 people, with the number of players two groups with a total of 8-10 people scrambling with each other, the media areca or bamboo lodong (kind of Sundanese bamboo) with 8-10 Meter long, where on it has been saved a variety of prizes 
scramble, areca nut / bamboo stained with oil, in this game dexterity, integrity and mutual cooperation is very reliable.

k. Oray-orayan: this is the Children's games imitating the behavior of snakes looking for prey, and housed in the yard or yard, played by children with a total of 10-20 people or more. By the rules of the game the leader or head of the snake is sought for the biggest child (snake's head) while on his hips, followed by the other children behind by holding the shoulder of the snake's head (the foremost child) to form a snake pattern, usually the youngest child becomes a tail/snake tail, after the formation they sang the same orayorayan kakawihan (Sundanese song) at the same time and the snake head (the front child) tried to catch the snake tail (the last child) with the code saying "kok ... kok ... kok ..." the tail or most child the back must be prepared to avoid the head of a snake, with a note that the snake body should not be separated.

1. Pacici-cici Putri: this is the Children's games and chants that use the lyrics of the song Pacici-cici daughter. This game is held at leisure, usually in the afternoon between 16:00 to 17:00 and is played by girls between 4-8 people, and the lyrics are as follows: Pacicicici putri...serelek kembang celempung... ali-ali pamadatan...goring adat tigrubas...kalau mau kembang apa ?, then the child who is asked to answer "KembangPacar". And other children must simultaneously sing rampak: manona ... manona ... si (the child's name).

m. Paciwit-ciwit lutung: this is the Children's play, ciwit which means pinching, paciwitciwitlutung (black-haired monkey pinching) is not pinching to make friends hurt, but putting hands on the back of his hand like pinching, this game is done by two people one child or more hands pinching each other's backs of his friend's hands until the hands are piled up, while singing: paciwit-ciwit lutung... si lutung pindah ka luhur..., when it said "pindahkaluhur" the lower hand moved upwards and so on.

n. Perepet Jengkol: Boys playing while singing kakawihanperepetjengkol, moving each of them using one foot, performed at the home or school. And this game can be a race if played by many groups to maintain their unity not to break or break the link kai-foot, and the longest to be the winning group. How to play each child chooses his group, then holds each other's hands and backs to each other, then the left or right leg of each child is connected to the hand that is holding followed by the other legs which lock together, so that the legs are not easily separated, then standing and tiptoeing on the spot while singing kakawihanperepetjengkol while maintaining the foot so it does not come loose with the group foot. 
o. Saptonan: This is the game and tradition of the Kuningan Regency ancestors, which is still performed in every Cigugurseren ritual, with a different pattern, each male participant must be able to ride and be given a spear by the committee, with a hole to throw the spear, this game trains the agility of the player, played versus or in a group on the field.

\section{Discussion}

From the results of the above description in a comprehensive manner, it is found that there are 15 (fifteen) traditional games often raised or documented in the ritual procession of SerenTaunheld on Rayagung $22^{\text {nd }}$ in Cigugur, Kuningan Regency, including: (1) Ambilambilan, (2) Ayang-ayanggung, (3) Babandringan, (4) Cingcangkeling, (5) Egrang (jajangkungan), (6) Endeuk-endeukan, (7) Gatrik, (8) Hahayaman, (9) Het-het embejanggotan, (10) Maen Rebutan (Panjat Pinang), (11) Oray-orayan, (12) Pacici-ciciputri, (13) Paciwitciwit Lutung, (14) Perepet Jengkol, (15) Saptonan/Penombak Berkuda. From these 15 (Fifteen) traditional games, it turns out that each game has a classification of main character values consisting of (1) Religious, (2) Nationalist, (3) Independent, (4) Mutual cooperation (cooperation), and (5) Integrity. Classification of character values in the collection of traditional games in traditional rituals of SerenTaunnCigugurKuningancanbe seen in the table below:

Table 1. Character Value Data Analysis of Traditional Games in Seren Taun Custom Rituals

\begin{tabular}{|c|c|c|c|c|c|c|}
\hline \multirow[t]{2}{*}{ No } & \multirow[t]{2}{*}{$\begin{array}{c}\text { Traditional Games } \\
\text { in SerenTaun Custom Rituals }\end{array}$} & \multicolumn{5}{|c|}{$\begin{array}{c}\text { Classification of five main character values } \\
\text { (Kemendikbud) }\end{array}$} \\
\hline & & $\mathbf{a}$ & $\mathbf{b}$ & $\mathbf{c}$ & $\bar{d}$ & $\mathbf{e}$ \\
\hline 1 & Ambil-ambilan & & & & $\checkmark$ & \\
\hline 2 & Ayang-ayanggung & & & & $\checkmark$ & \\
\hline 3 & Babandringan & & & & & $\checkmark$ \\
\hline 4 & Cingcangkeling & & & & $\checkmark$ & \\
\hline 5 & Egrang (jajangkungan) & & & $\checkmark$ & & \\
\hline 6 & Endeuk-Endeukan & & & & $\checkmark$ & \\
\hline 7 & Gatrik (tokle) & & & & & $\checkmark$ \\
\hline 8 & Hahayaman & & & $\checkmark$ & & \\
\hline 9 & Het-het embejanggotan & & & & & \\
\hline 10 & MaenRebutan (Panjat Pinang) & & & $\checkmark$ & $\checkmark$ & $\checkmark$ \\
\hline 11 & Oray-orayan & & & & $\checkmark$ & \\
\hline 12 & Pacici-ciciputri & & & $\checkmark$ & & \\
\hline 13 & Paciwit-ciwitlutung & & & $\checkmark$ & & \\
\hline 14 & PerepetJengkol & & & & $\checkmark$ & \\
\hline 15 & $\begin{array}{l}\text { Saptonan } \\
\text { (MenombakdanBerkuda) }\end{array}$ & & & & & $\checkmark$ \\
\hline
\end{tabular}

Notes: (a) Religious, (b) Nationalist, (c) Independent, (d) Mutual cooperation (cooperation), (e) Integrity, 
It is found that of the 15 traditional games often raised or documented in the ritual procession of SerenTaunheld on Rayagung $22^{\text {nd }}$ in Cigugur, Kuningan Regency, the researchers gain the following interpretations: 5 (five) types of games have the potential value of Independent characters including: (1) Egrang, (2) Hahayaman, (3) MaenRebutan (panjatpinang), (4) Pacici-ciciputri, and (5) Paciwit-ciwitlangur. Whereas the traditional games that have the potential value of the Mutual Cooperation characters are identified as many as 7 (seven) games including: (1) Ambil-ambilan, (2) Ayang-ayanggung, (3) Cingcangkeling, (4) Endeuk-endeukan, (5) Maen Rebutan, (6) Oray-orayan, and (7) Perepet Jengkol. And the games classified as having main character value of Integrity are as many as 4 (four) games including: (1) babandringan, (2) Gatrik, (3) Maen Rebutan, (4) Saptonan (Menombak \& Berkuda). In the meantime, from the 15 traditional games in SerenTauncustom ritual, the researchers do not find the categorization of the character values of Religious or Nationalist.

\section{CONCLUSION}

The main objective of character education is to create quality and superior human resources based on the national education goals of the Republic of Indonesia. It turns out that the values of character education in one of the ancestral heritages, such as traditional games that have existed since long time ago and were passed down from generation to generation, have implied values of Character Education. But inequality occurs when the younger generation does not preserve it, which may be caused by the times. In fact, traditional children's games can be an alternative to creating a generation of superior character. Furthermore, from the 15 traditional game sets in the SerenTaunofCigugur traditional ritual, after the classification of the potential values of the main characters, the findings are as follows: (a). 5 (five) types of games have potential value of main independent character or as many as $33 \%$, (b). 7 (seven) games have main character value of mutual cooperation or as many as $46 \%$, and (c). 4 (four) types of games havemain character value of integrity or as many as $27 \%$. In the meantime, the value of religious main characters and nationalist main character values of some games in SerenTaun traditional ritual are not yet included in that category.

\section{ACKNOWLEDGMENTS}

This research activity is sponsored by LPPM Kuningan University in the Program of Penelitian Dosen Pemula (PDP) of the 2019/2020 Budget Year and funded by the Directorate and Community Service of Directorate General of Research and Development of the Ministry of Research, Technology, and Higher Education for the 2020 budget year.

\section{REFERENCES}

Adisaputri, Y. D., \& Widiastuti, I. (2015). Territorial identification of vernacular settlement Cigugur through the practice of Seren Taun Ritual in Kuningan, West Java. Procedia Social and Behavioral Sciences, 184(August 2014), 196-205.

Aditya, Y. A. (2013). Nilai-nilai kearifan lokal masyarakat Cigugur-Kuningan dalam 
pelestarian lingkungan hidup sebagai sumber belajar Geografi. Jurnal Gea, 13(2), 20-32.

Andriani, T. (2012). Permainan tradisional dalam membentuk karakter anak usia dini. Sosial Budaya, 9(1), 121-136. Retrieved from http://ejournal.uinsuska.ac.id/index.php/SosialBudaya/article/view/376/358

Emerson, R. M., Fretz, R. I., \& Shaw, L. L. (1995). Writing ethnography fieldnotes. Chicago: The University of Chicago Press.

Hemafitria. (2019). Nilai karakter berbasis kearifan lokal tradisi tepung tawar pada etnis Melayu Sambas. Jurnal Pendidikan Kewarganegaraan, 3(2), 121-132.

Holilah, M. (2015). Kearifan ekologis budaya lokal masyarakat adat Cigugur sebagai sumber belajar ips. Jurnal Pendidikan Ilmu Sosial, 24(2), 1-16.

Kamarusdiana. (2019). Studi etnografi dalam kerangka masyarakat dan budaya. SALAM: Jurnal Sosial Dan Budaya Syar-I, 6(2), 113-128.

Kemdikbud. (2014). Konsep dan implementasi kurikulum 2013. Jakarta.

Kemdiknas. (2010). Pengembangan pendidikan budaya dan karakter bangsa. Jakarta: Balitbang Puskur Kemdiknas.

Kurnia, L. (2014). "Seren Taun " between hegemony and culture industry. Wacana, 15(2), $300-313$.

Lickona, T. (2012). Mendidik untuk membentuk karakter. Jakarta: Bumi Aksara.

Nur, H. (2013). Building children's character through traditional games. Junal Pendidikan Karakter, 3(1), 87-94.

Purwaningsih, E. (2006). Permainan tradisional anak: salah satu khasanah budaya yang perlu dilestarikan. Jantra, 1(1), 40-46.

Rosidi. (2000). Ensiklopedia Sunda alam, manusia, dan budaya: termasuk budaya Cirebon dan Betawi (cetakan pertama). Jakarta: PT Dunia Pustaka Jaya.

Royyani, M. F. (2008). Upacara Seren Taun di Cigugur, Kabupaten Kuningan, Jawa Barat: tradisi sebagai basis pelestarian lingkungan. Jurnal Biologi Indonesia, 4(5), 399-415.

Spradley, J. P. (2007). Metode etnografi. Yogyakarta: Tiara Wacana.

Subiantoro, I. H. (2016). Estetika, Seren Taun antara seni, ritual, dan kehidupan. Panggung, 26(4), 407-419. https://doi.org/10.26742/panggung.v26i4.212

Subiantoro, I. H. (2017). Pergelaran Ritual Seren Taun di Cigugur Kabupaten Kuningan Jawa Barat. Patrawidya, 18(1), 41-55.

Suhaenah, E., Rohaeni, A. J., \& Listiani, W. (2017). Rekontruksi Pikukuh Tilu dalam manajemen Babarit pada Upacara Serentaun Cigugur Kuningan. Panggung, 27(2), 168176.

Suyatna, A. (2007). Modul model-model pembelajaran. Bandar Lampung: Universitas Lampung.

Wibowo, A. (2008). Kajian tentang perilaku pengguna sistem informasi dengan pendekatan technology acceptance model (tam). Konferensi Nasional Sistem Informasi 2008: Indonesia Modern Dalam Budaya Informasi. Yoogyakarta: Universitas Sanata Dharma Yogyakarta. 